\title{
Tracking foraging green turtles in the Republic of the Congo: insights into spatial ecology from a data poor region
}

\author{
Kristian Metcalfe, Nathalie Bréheret, Gä̈lle Bal, Eva Chauvet \\ Philip D. Doherty, Angela Formia, Alexandre Girard \\ Jean-Gabriel Mavoungou, Richard J. Parnell \\ Stephen K. Pikestey and Brendan J. Godery
}

\begin{abstract}
Globally, marine turtles are considered threatened throughout their range, and therefore conservation practitioners are increasingly investing resources in marine protected areas to protect key life history stages and critical habitats, including foraging grounds, nesting beaches and inter-nesting areas. Empirical data on the distribution of these habitats and/or the spatial ecology and behaviour of individuals of many marine turtle populations are often lacking, undermining conservation efforts, particularly along the Atlantic coast of Africa. Here we contribute to the knowledge base in this region by describing patterns of habitat use for nine green turtles Chelonia mydas tagged with satellite platform transmitter terminals at a foraging ground in Loango Bay, Republic of the Congo, one of only a few documented mainland foraging grounds for marine turtles in Central Africa. Analyses of these data revealed that core areas of habitat use and occupancy for a wide range of size/age classes were restricted to shallow waters adjacent to Pointe Indienne in Loango Bay, with most individuals showing periods of high fidelity to this area. These data are timely given the Congolese government recently announced its intention to create a marine conservation zone to protect marine turtles in Loango Bay. Despite the small sample size of this study, these data exemplify the need for comprehensive
\end{abstract}

Kristian Metcalfe (Corresponding author), Philip D. Doherty, Stephen K. Pikesley ${ }^{*}$ and Brendan J. Godley Centre for Ecology and Conservation, College of Life and Environmental Sciences, University of Exeter, Penryn Campus, Penryn, Cornwall, UK. E-mail kristian.metcalfe@exeter.ac.uk

Nathalie Bréheret (Corresponding author) GaËlle Bal, Eva Chauvet $\dagger$ and Jean-Gabriel Mavoungou, Association Renatura Congo, Ecocentre, Rue Bois des Singes, B.P. 414, Pointe Noire, Republic of the Congo

E-mail direction@renatura.org

Angela Formia Wildlife Conservation Society, Gulf of Guinea Sea Turtle Program, Libreville, Gabon

AleXandRe GIRARD RENATURA France, Paris, France

Richard J. Parnell Wildlife Conservation Society, Gabon Program, Libreville, Gabon

*Also at: Environment and Sustainability Institute, University of Exeter, Penryn Campus, Penryn, Cornwall, UK

$\dagger$ Current address: Fédération Régionale des Centres d'Information sur les Droits des Femmes et des Familles, Marseille, France

Received 6 November 2018. Revision requested 11 February 2019.

Accepted 12 March 2019. First published online 3 February 2020. strategies that span national jurisdictions, as we provide the first documented evidence of linkages between green turtle foraging sites in Central Africa (Loango Bay, Republic of the Congo) and Southern Africa (Mussulo Bay, Angola).

Keywords Angola, Chelonia mydas, Congo, foraging, green turtle, habitat use, life history, spatial ecology

Supplementary material for this article is available at doi.org/10.1017/So030605319000309

\section{Introduction}

any large marine species, including sharks, marine 1 turtles and cetaceans, are considered threatened throughout their range and require targeted management strategies to support their conservation (Lewison et al., 2004; Hoffmann et al., 2010). The advent of so-called biologging, along with recent improvements in tag size, battery duration and location accuracy (Hays et al., 2016), means that we now know more about the complex life history characteristics and migratory life cycles of many marine vertebrates, information that can be used to inform conservation strategies, particularly for marine turtles (Hazen et al., 2012). Large adult female marine turtles come ashore during short nesting periods, and juveniles and adults can be captured in-water, after which it is relatively easy to attach satellite and/or GPS platform transmitter terminals (PTTs) to their carapace (Jeffers \& Godley, 2016). Such application has revealed insights into the breeding, migratory, foraging and spatial ecology of hatchling, juvenile and adult marine turtles (Luschi et al., 2003; Mansfield et al., 2014).

There remain, however, data gaps in some regions that host globally important populations of marine turtles, hindering conservation efforts (Hamann et al., 2010; Mazaris et al., 2014). This is most notable for juveniles globally (Wildermann et al., 2018) and for all life stages along the Atlantic coast of Africa (Formia et al., 2003), where the status of several species and populations is considered Data Deficient (IUCN, 2017). Although research has increased in this region, it has primarily focused on monitoring nesting populations, leading to the identification of globally important 
nesting aggregations of leatherback Dermochelys coriacea, olive ridley Lepidochelys olivacea and green Chelonia mydas marine turtles (Witt et al., 2009; Metcalfe et al., 2015; Patrício et al., 2017, and references therein). Foraging grounds have, however, remained largely understudied despite records of their occurrence from Banc d'Arguin in Mauritania, West Africa, to Mussulo Bay in Angola, Southern Africa (Carr \& Carr, 1991; Fretey, 2001; Cardona et al., 2009). As a result, conservation strategies have largely been directed at identifying threats, and establishing new or expanding existing protected areas to protect key nesting beaches and inter-nesting habitats (Witt et al., 2008; Maxwell et al., 2011; Pikesley et al., 2018). Foraging grounds thus remain largely unprotected throughout the region, undermining ongoing conservation efforts for species such as the green turtle, which moves ontogenetically, with juveniles actively recruiting to neritic development habitats following several years of passive pelagic migration and then migrating to an adult foraging habitat that may also be shared with juveniles (Bjorndal, 2017).

Given their proximity to the coast, neritic developmental and foraging habitats are often exposed to a diverse range of pressures, including from fisheries, direct take, and habitat degradation linked to coastal development and marine pollution, with impacts on green turtles exacerbated by their slow growth, late onset of sexual maturity and low survivorship (Hirth, 1997). Therefore, understanding how green turtles use foraging habitats is essential to support more coherent marine spatial planning and conservation efforts, particularly as ontogenetic strategies may vary between genetic stocks or regional management units (Hamann et al., 2010). This is where satellite tracking can play a role, revealing the location and extent of important foraging habitats such as seagrass beds and macroalgal dominated reefs (Scott et al., 2012; Hays et al., 2018). Tracking animal movements can also highlight variability in life history patterns among disparate populations (Bolten, 2003; Godley et al., 2008) such as the links between discrete foraging grounds and the degree of fidelity shown to these areas (Stokes et al., 2015).

To address the absence of knowledge on foraging grounds and inform conservation strategies along the Atlantic coast of Africa, we analyse historical satellite tracking data to provide the first description of the spatial ecology and movement of green turtles tagged with PTTs at a neritic foraging ground in Loango Bay, Republic of the Congo. Access to these data are timely given the Republic of the Congo recently announced its intention to create a marine conservation zone in Loango Bay to protect marine turtles and sharks (Our Ocean, 2016).

\section{Study area}

The Republic of the Congo is situated on the Atlantic coast of Central Africa, with Loango Bay, the focus of this study, $20 \mathrm{~km}$ north of the port city and economic capital, Pointe
Noire (Fig. 1). Loango Bay covers an area of c. $100 \mathrm{~km}^{2}$, bounded by Pointe Indienne to the south, and the Kouilou river mouth to the north, and is characterized by shallow sheltered waters $(<10 \mathrm{~m}$ deep $)$ that comprise a mosaic of habitats, including macroalgal dominated rocky reefs, and silt laden and sandy bottom habitats (Giresse et al., 1980; Malounguila-Nganga et al., 2017), which support a wide range of marine species (Girard et al., 2014).

\section{Methods}

\section{Satellite tracking data collection and processing}

Telonics Inc. (Mesa, Arizona, USA) satellite PTT models TGM-4310-2 (153 $\mathrm{g}$ in air; $\mathrm{n}=2)$, TGM-4410-2 (262 $\mathrm{g}$ in air; $n=3$ ), and TAM-4510 (435 $\mathrm{g}$ in air; $\mathrm{n}=5$ ) were attached to 10 green turtles (individuals A-J) incidentally captured by artisanal fishers operating in Loango Bay and subsequently released at Pointe Indienne (Table 1, Fig. 1). PTTs were deployed during 2012-2014, with two deployments each in February, April and August, one deployment each in May, September, November and December, attached in accordance with established protocols (Godley et al., 2002).

Data transmitted by PTTs were collected using the Argos satellite system and downloaded with the Satellite Tracking and Analysis Tool (Coyne \& Godley, 2005). For each PTT we used extremely parsimonious filters, per Varo-Cruz et al. (2016), removing all positions with location class $Z$ and $\mathrm{o}$, and retaining positions with classes $\mathrm{A}, \mathrm{B}, 1,2$ and 3 , and applied a user-defined speed threshold $(>5 \mathrm{~km} / \mathrm{h})$ and azimuth filter $\left(<20^{\circ}\right)$, to remove implausible Argos locations (Freitas et al., 2008; Witt et al., 2010) using the argosfilter package in $R$ 3.5.o (R Core Team, 2018). For each PTT, data were then resolved to single daily best quality locations (per Witt et al., 2010). If more than one location was determined with equal quality within a 24 -h period, the first location was retained. This data reduction technique was adopted to minimize the spatial and temporal autocorrelation that inherently exists within animal movement tracking data sets (De Solla et al., 1999).

\section{Spatial analyses}

For each PTT we calculated daily and maximum displacement distance $(\mathrm{km})$ from release location, and applied three established techniques typically used to describe core areas of occupancy and habitat use for a wide range of marine vertebrates (manta rays: Graham et al., 2012; basking sharks: Doherty et al., 2017; marine turtles: Winton et al., 2018): (1) 95\% minimum convex polygons (MCPs), (2) a polygon sampling grid, and (3) kernel density estimation. Ninety-five percent MCPs were calculated using all filtered locations (excluding $5 \%$ of the most extreme locations from 

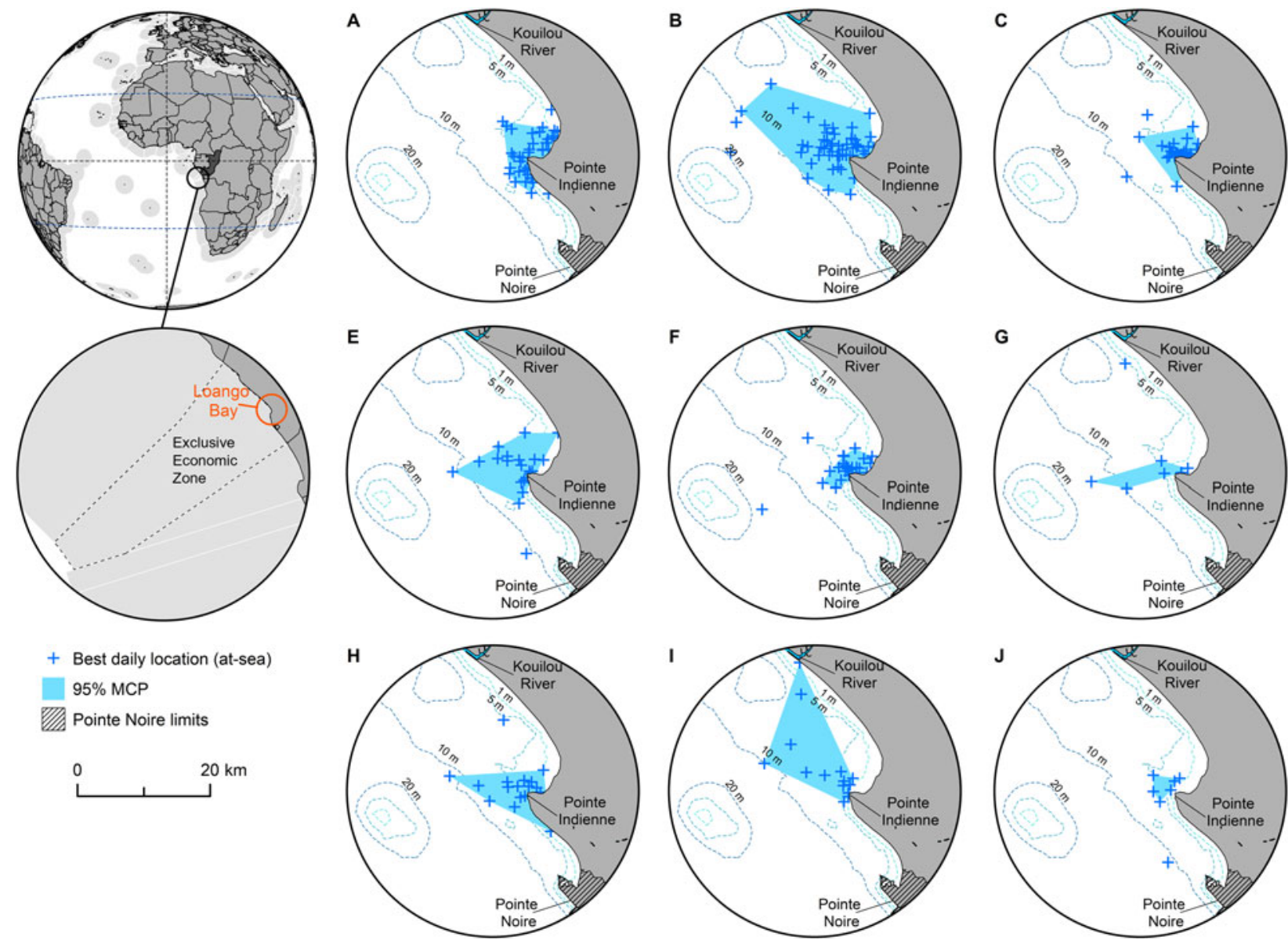

FIG. 1 Ninety-five percent minimum convex polygon (MCP) home ranges for each of nine individual green turtles Chelonia mydas tagged in Loango Bay, Republic of the Congo (Table 1, excluding individual D), derived from best daily locations at-sea. The 95\% MCP for individual I is based on movements within foraging ground, clipped to 26 March 2013, the date this individual departed Loango Bay and started its migration south to Mussulo Bay, south of Luanda, Angola (Supplementary Figs 3 \& 4).

TABLE 1 Metadata for each of the 10 green turtles Chelonia mydas tagged with satellite platform transmitter terminals (PTTs) in Loango Bay, Republic of the Congo. All individuals were released at Pointe Indienne.

\begin{tabular}{|c|c|c|c|c|c|c|c|c|}
\hline Individual & PTT ID & PTT model & $\begin{array}{l}\mathrm{CCL}^{1} \\
(\mathrm{~cm})\end{array}$ & $\begin{array}{l}\mathrm{CCW}^{2} \\
(\mathrm{~cm})\end{array}$ & Start-end dates & $\begin{array}{l}\text { Duration } \\
\text { (days) }\end{array}$ & $\begin{array}{l}\text { Max. displacement } \\
(\mathrm{km})\end{array}$ & $\begin{array}{l}95 \% \mathrm{MCP} \\
\left(\mathrm{km}^{2}\right)\end{array}$ \\
\hline $\mathrm{A}$ & 115081 & TAM-4510 & 90 & 80 & $21 / 04 / 2012-16 / 08 / 2012$ & 117 & 38.0 & 54.2 \\
\hline B & 115083 & TAM-4510 & 78 & 71 & $20 / 04 / 2012-28 / 09 / 2012$ & 161 & 48.9 & 191.0 \\
\hline $\mathrm{C}$ & $115070 \mathrm{a}$ & TGM-4310-2 & 39 & $\mathrm{n} / \mathrm{a}$ & $02 / 05 / 2012-12 / 07 / 2012$ & 71 & 20.4 & 41.7 \\
\hline $\mathrm{D}^{3}$ & $115070 \mathrm{~b}$ & TGM-4310-2 & 44 & 39.5 & $02 / 08 / 2012-02 / 08 / 2012$ & 0 & & \\
\hline $\mathrm{E}$ & 115074 & TGM-4410-2 & 48.2 & 44.7 & $02 / 08 / 2012-21 / 11 / 2012$ & 111 & 25.5 & 81.4 \\
\hline $\mathrm{F}$ & 115077 & TAM-4510 & 74 & 64 & $12 / 09 / 2012-09 / 12 / 2012$ & 88 & 15.2 & 23.4 \\
\hline G & 115072 & TGM-4410-2 & 43.3 & 40.5 & $27 / 11 / 2012-20 / 12 / 2012$ & 23 & 18.8 & 26.1 \\
\hline $\mathrm{H}$ & 115073 & TGM-4410-2 & 43 & 42 & 20/02/2013-07/06/2013 & 107 & 11.8 & 68.9 \\
\hline $\mathrm{I}^{4}$ & 115080 & TAM -4510 & 74 & 68 & $20 / 02 / 2013-26 / 03 / 2013$ & 34 & $56.0(505.9)$ & 132.4 \\
\hline $\mathrm{J}$ & 115075 & TAM- 4510 & $\mathrm{~nm}^{5}$ & $\mathrm{~nm}^{5}$ & $18 / 12 / 2014-28 / 12 / 2014$ & 9 & 10.8 & 9.2 \\
\hline
\end{tabular}

${ }^{1}$ Curved carapace length $(\mathrm{cm})$.

${ }^{2}$ Curved carapace width $(\mathrm{cm})$.

${ }^{3}$ Tag failed $<24 \mathrm{~h}$ after deployment.

${ }^{4}$ Max. displacement and MCP are based on movements within foraging ground, clipped to 26 March 2013 , this being the date this individual departed Loango Bay and started migration south to Mussulo Bay, south of Luanda, Angola (total displacement post release in parentheses).

${ }^{5}$ Not measured. 
the centroid of these data) for each individual turtle, and for combined individuals each month. For the polygon sampling, a $3.5 \mathrm{~km}^{2}$ hexagonal grid was constructed and spatially intersected with locations to derive a count of the total number of unique turtles recorded per grid cell. The mean proportion of locations was also calculated based on the proportion of locations recorded within each grid cell for each individual. Kernel density estimation was used to describe habitat use, and calculated using methods that account for physical barriers that can prevent movement for marine species (i.e. land; Sprogis et al., 2016). The output cell size was $50 \times 50 \mathrm{~m}\left(0.0025 \mathrm{~km}^{2}\right)$ and the bandwidth (search radius that determines the surrounding locations, which contribute to the estimation) was set to $1,500 \mathrm{~m}$. The choice of a bandwidth selection method may vary depending on the study goals, sample size and patterns of space use by the study species (Gitzen et al., 2006), and therefore the bandwidth value was chosen by iterative visual inspection of outputs (per Sprogis et al., 2016). The output from kernel density estimation thus represents the estimated density of locations per $\mathrm{km}$ that are likely to occur within each grid cell, from which we extracted $95,75,50$ and $25 \%$ utilization distributions. Finally, to describe habitat use within Loango Bay we calculated the proportion of locations within 10 seabed depth classes at $10 \mathrm{~m}$ intervals, and 10 offshore distance classes at $1 \mathrm{~km}$ intervals, for each tagged individual. Seabed depth $(\mathrm{m})$ and offshore distance $(\mathrm{km})$ values were assigned to each daily location using General Bathymetric Chart of the Oceans gridded data (resolution 30 arc-seconds; Weatherall et al., 2015), and fine-scale coastline data extracted from Landsat data $(\mathrm{Xu}, 2006)$, respectively.

\section{Results}

\section{Deployment summary, size distribution, tracking duration and displacement distance}

Of the 10 turtles tagged with satellite PTTs, one tag was excluded from subsequent analyses as it failed $<24 \mathrm{~h}$ post deployment (individual D; Table 1). For eight of the remaining nine tagged the turtles' body size data were available (curved carapace length, CCL: $39.0-90.0 \mathrm{~cm}$, mean $61.2 \pm \mathrm{SD} 19.8 \mathrm{~cm}$, median $61.1 \mathrm{~cm}$, IQ range $43.2-$ $75.0 \mathrm{~cm}$; Table 1). These nine individuals were tracked for 9-161 days (mean $80 \pm$ SD 50 days, median 88 days, IQ range 34-111 days; Table 1), with maximum displacement distance from release locations within the foraging ground of 10.8-56.0 km (mean $27.3 \pm$ SD $16.5 \mathrm{~km}$, median $20.4 \mathrm{~km}$, IQ range $15.2-38.0 \mathrm{~km}$; Table 1, Supplementary Fig. 1). There was no significant relationship between the size of individuals and tracking duration (days) or maximum displacement distance $(\mathrm{km})$ from release locations (all P > 0.05; Supplementary Fig. 2).

\section{General movements, core areas and habitat use}

Of the nine tagged individuals that transmitted location data post deployment, eight remained within the vicinity of Pointe Indienne in Loango Bay (Supplementary Fig. 3) for 9-161 days (Table 1). One individual (I; Supplementary Fig. 3), however, migrated south after 34 days (Table 1 ). This took the turtle a minimum distance of $505.9 \mathrm{~km}$ along the continental shelf $(<200 \mathrm{~m}$ depth $)$ over a period of c. 16.5 weeks (mean minimum speed $0.5 \pm \mathrm{SD} 0.5 \mathrm{~km} / \mathrm{h}$, median $0.3 \mathrm{~km} / \mathrm{h}$, IQ range $0.1-0.8 \mathrm{~km} / \mathrm{h}, \mathrm{n}=18$ locations) to foraging grounds in Mussulo Bay, Angola (Supplementary Fig. 4) where it remained for 30 days till cessation of tracking.

Prior to analyses of core areas, telemetry data for individual I (Table 1) was clipped at 26 March 2013, this being the date this turtle left the Loango Bay foraging ground (Supplementary Fig. 4). Within Loango Bay individual core areas of occupancy (based on $95 \% \mathrm{MCPs}$ ) of the nine individuals were $9.2-191.0 \mathrm{~km}^{2}$ (mean $69.8 \pm \mathrm{SD} 58.6 \mathrm{~km}^{2}$, median $54.2 \mathrm{~km}^{2}$, IQ range $26.1-81.4 \mathrm{~km}^{2}$; Table 1, Fig. 1). There was, however, no significant relationship between the CCL of individuals and the size of core areas (P $>0.05$; Supplementary Fig. 2). Analyses of monthly variation revealed that core areas of occupancy (based on MCPs) did not vary systematically and were probably driven more by data volume and ARGOS location quality. MCPs ranged between $6 \mathrm{~km}^{2}$ in November to $168.8 \mathrm{~km}^{2}$ in June (mean $69.0 \pm \mathrm{SD} 53.6 \mathrm{~km}^{2}$, median $56.9 \mathrm{~km}^{2}$, IQ range $27.7-100.2 \mathrm{~km}^{2}, \mathrm{n}=11$ months; Supplementary Fig. 5).

In terms of habitat use, there was no evidence of size-related niche partitioning, with individuals of all sizes using similar depth zones and distances offshore (Supplementary Fig. 6). Analysis of location data by depth and offshore distance revealed that all size classes had a preference for waters $<10 \mathrm{~m}$ deep (mean proportion of locations $<10 \mathrm{~m} 0.64 \pm \mathrm{SD} 0.14$, median 0.60 , IQ range $0.56-0.72$; Fig. 2) within $3 \mathrm{~km}$ of the coast (mean proportion of locations $<3 \mathrm{~km}$ offshore $0.69 \pm$ SD 0.15 , median 0.67 , IQ range 0.57-0.81; Fig. 2). Location of high use areas (i.e. areas with high occupancy; $>10 \%$ of locations, and $50 \%$ utilization distribution) were restricted to shallow waters adjacent to and surrounding Pointe Indienne in Loango Bay (Fig 2).

\section{Discussion}

Marine turtles are migratory, often travelling great distances between natal beaches and foraging areas, and/or between foraging areas and reproductive sites (Godley et al., 2008). Yet for many of the world's marine turtle populations empirical data on the distribution and condition of important foraging areas, or the behaviour and ecology of individuals in these habitats, are lacking (Rees et al., 2016; Williams et al., 2017). Describing marine turtle foraging grounds, including information on species, abundance, size/age classes 

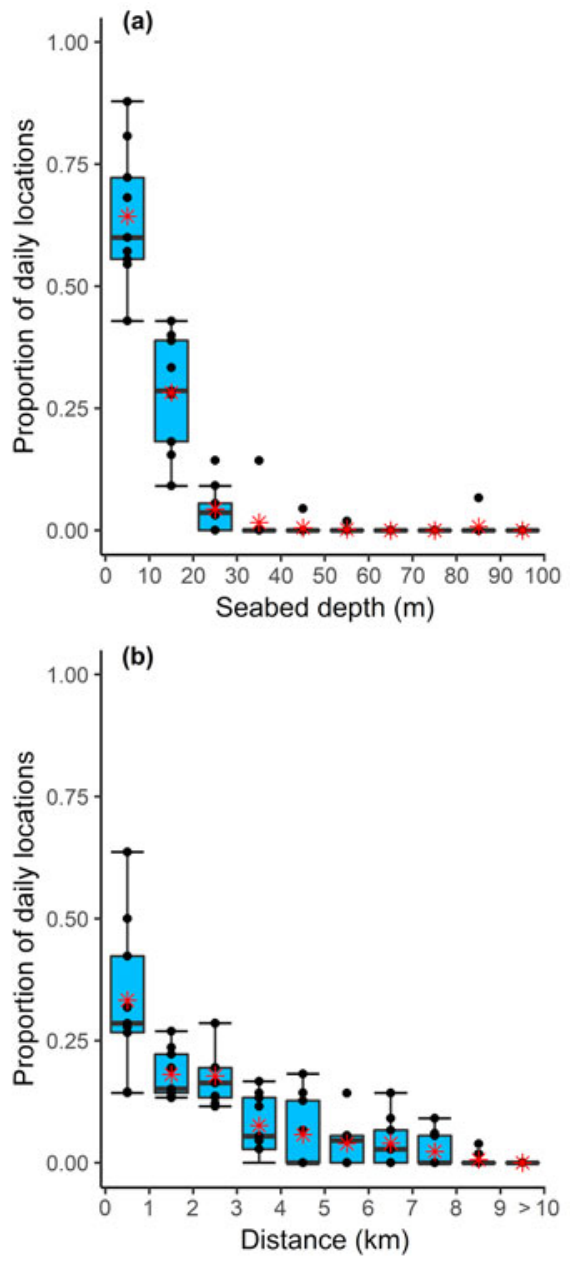
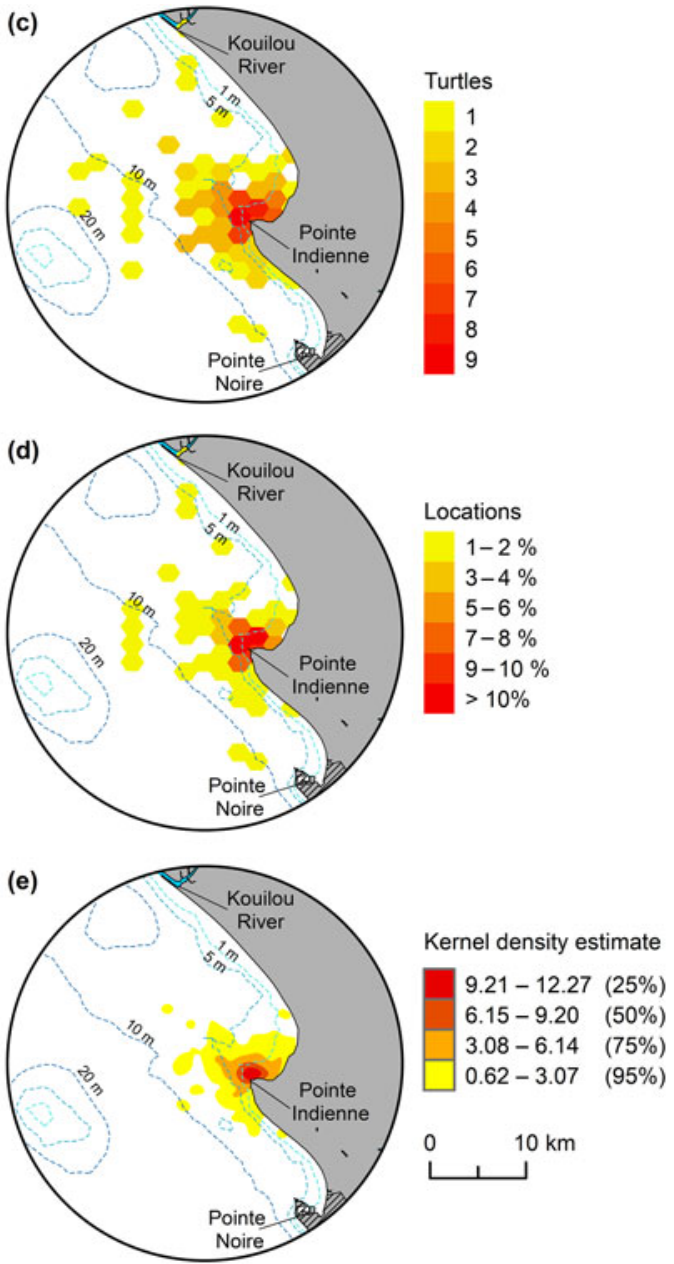

FIG. 2 Green turtle habitat use in Loango Bay. Proportion of daily locations by: (a) seabed depth, and (b) offshore distance for the nine tagged individuals (Table 1). Boxplots depict the 25th, 5oth (median) and 75th percentiles, with mean value for each depth and offshore distance class represented by an asterisk. Core areas of occupancy for green turtles in Loango Bay: (c) grid count of unique number of turtles per hexagon, (d) mean proportion of daily locations derived from each tagged individual, and (e) kernel density estimate with $25,50,75$ and $95 \%$ utilization distributions, derived from best daily locations at-sea. present, area of occupancy, habitat preferences, and temporal patterns of their use, is key for effective conservation planning and targeted management (Casale et al., 2012; Chevis et al., 2017; Williams et al., 2017). Our findings show how satellite tracking can facilitate insights into the spatial ecology and behaviour of green turtles at one of only a few documented mainland foraging grounds in Central Africa, Loango Bay in the Republic of the Congo, a country that despite hosting five species of marine turtle (Godgenger et al., 2009) is poorly documented in the scientific literature.

The deployment of satellite tags on marine turtles incidentally captured by artisanal fishers operating in Loango Bay and subsequently released at Pointe Indienne revealed that green turtles generally exhibited high site fidelity to the foraging grounds within Loango Bay. Our data also show that Loango Bay foraging grounds comprise mixed size/age classes, with little variation in area of occupancy across individuals and no clear evidence of size-related niche partitioning commonly seen at other foraging grounds (Arthur et al., 2008; Ballorain et al., 2010). Core areas of occupancy for all size/age classes (defined as the
$50 \%$ utilization distribution) covered an area of $5.6 \mathrm{~km}^{2}$ and were located in the shallow waters around Pointe Indienne in Loango Bay, with the majority of tagged individuals utilizing this same restricted area for 1-23 weeks prior to the tags ceasing transmission. Recent studies have shown that Loango Bay is subject to intensive small-scale fishing pressure (Metcalfe et al., 2017), and maritime vessel activity linked to shipping and the offshore petrochemical sector (Metcalfe et al., 2018). The findings of this study thus validate calls to increase protection of nearshore habitats surrounding Pointe Indienne as excessive bycatch in fisheries, seismic surveys, oil pollution and coastal development can lead to behavioural changes, exclusion from or damage to critical habitats, and physical damage or mortality (Casale \& Heppell, 2016; Nelms et al., 2016; Duncan et al., 2017; Wallace et al., 2017; Ylitalo et al., 2017). The site fidelity shown by most tagged individuals also reinforces the potential utility of implementing a marine protected area in Loango Bay; even a moderate sized area of $5.6-76.4 \mathrm{~km}^{2}$ (50 and $95 \%$ utilization distributions) would offer significant protection to green turtles in high density foraging areas (Broderick et al., 2007; Scott et al., 2012). In this case 
the density and fidelity is probably largely driven by the extensive use of macroalgal dominated rocky reefs, a geological extension of Point Indienne into Loango Bay (Giresse et al., 1980; Malounguila-Nganga et al., 2017), and so should form a key component of any proposed marine protected area.

Although most of the tagged individuals remained within the waters of the Republic of the Congo, satellite telemetry data provided the first documented evidence of linkages between discrete foraging grounds in Central and Southern Africa, with one individual migrating south $505.9 \mathrm{~km}$ from Loango Bay, Republic of the Congo, to Mussulo Bay, Angola, a $152 \mathrm{~km}^{2}$ area that during 1983-1985 was documented to contain extensive coral, algal and seagrass flats (Carr \& Carr, 1991). Given that green turtles are important indicators of habitat presence and condition (Scott et al., 2012; Hays et al., 2018) these findings suggest that this area, c. 30 years after its only documented survey, still contains resources to host green turtles. Few data are available on the abundance of green turtles in Mussulo Bay, but boat-based surveys and interviews conducted by Carr \& Carr (1991) revealed that although juvenile, subadult and adult green turtles were present year-round (although there was seasonal variation in numbers), nesting was rare. Given these insights and the small sample size of our study it is important to interpret these findings cautiously. There are, however, three possible explanations for this movement. Firstly, given the small size of the individual tracked (individual I: CCL 74 $\mathrm{cm}$; Table 1 ) relative to nesting adult females in the Gulf of Guinea (CCL: $98.3 \pm$ SD $6.1 \mathrm{~cm}$; Tomás et al., 2010) and the fact that Loango Bay predominantly comprises macroalgae, this behaviour could represent an ontogenetic shift from juvenile to adult foraging grounds as Mussulo Bay is dominated by seagrass and so may be more suited to the dietary or energy requirements of larger animals. Secondly, given the departure date coincides with the end of the nesting season (September-April; Godgenger et al., 2009) this behaviour could be evidence of post-nesting migration to adult foraging habitat in Angola, a behaviour typically observed in green turtles, with individuals often having high fidelity to specific foraging locations between breeding seasons (Broderick et al., 2007; Garnier et al., 2012). Thirdly, this individual may have been tagged following migration from neritic developmental habitats elsewhere in the Gulf of Guinea, such as Corisco Bay, Gabon (given its proximity, c. $750 \mathrm{~km}$ ), whilst on route to adult foraging habitat in Angola. Genetic analyses could help by providing detailed information of stock and natal origin (Bowen \& Karl, 2007) that could disentangle the connections that exist among this and other green turtle rookeries and foraging grounds along the Atlantic coast of Africa (Rees et al., 2016; Patrício et al., 2017, and references therein).

Despite marine turtles having been legally protected in the Republic of the Congo since 2011 (Order No. 6075 establishing the animal species fully and partially protected by Law No.
48/83 21/04/1983), the complex nature of the marine environment, and overlapping claims for space as well as political and economic provisions (Metcalfe et al., 2018), mean that it is extremely unlikely that the Congolese government will be able to fully protect the entire range over which marine turtles in our study were located. Nonetheless, significant efforts are being made by the Congolese government to implement a protected area in Loango Bay (Our Ocean, 2016), with a stakeholder led planning process underway (Congo Marine, 2018). If successful this would complement existing efforts to increase protection of marine turtle nesting beaches, internesting areas and foraging grounds in other range states along the Central African coast (e.g. Gabon; Dawson et al., 2017; Pikesley et al., 2018). Our findings will thus ensure there is increased awareness regarding the location of core areas and critical foraging habitats that should be protected from deleterious activities such as fisheries and coastal development. This is of particular concern given the high incidence of marine turtle bycatch in artisanal fisheries in Loango Bay (Girard et al., 2014). Finally, despite the small sample size of this study, our findings have also provided the first documented evidence of linkages between Loango Bay and other poorly studied foraging grounds in the region, exemplifying the need for further tracking, tagging and genetic studies, and comprehensive strategies that span national and international jurisdictions, if conservation efforts targeted at marine turtles in this region are to be effective.

Acknowledgements Rénatura Congo are supported by funding from the Marine Turtle Conservation Fund (U.S. Fish \& Wildlife Service, U.S. Department of the Interior). This study and data acquisition were supported by funding from the European Union, Total E\&P Congo and MPD/Xstrata. KM and BJG were supported by funding from The Waterloo Foundation and the Darwin Initiative (Projects 20-009/ 23-011/26-014), the latter through funding from the Department for Environment, Food and Rural Affairs in the UK. PDD was supported by a NERC Science Innovation Placement (NE/R007039/1). We thank two anonymous reviewers for constructive comments.

Author contributions Coordination, facilitation of fieldwork, deployment of satellite transmitters: NB, GB, AG, J-GM; data analysis: SKP, PDD, KM, BJG; data interpretation, writing: all authors.

\section{Conflicts of interest None.}

Ethical standards This research abided by the Oryx guidelines on ethical standards, and had approval from the University of Exeter Ethics committee, with appropriate permissions to conduct scientific research and disseminate findings provided by the Ministry of Scientific Research and Technological Innovation in the Republic of the Congo (Permits: No. 023/MRSIT/DGRST/DMAST and No. 167/ MRSIT/IRF/DS).

\section{References}

Arthur, K.E., Boyle, M.C. \& Limpus, C.J. (2008) Ontogenetic changes in diet and habitat use in green sea turtle (Chelonia mydas) life history. Marine Ecology Progress Series, 362, 303-311. 
Ballorain, K., Ciccione, S., Bourjea, J., Grizel, H., Enstipp, M. \& Georges, J.-Y. (2010) Habitat use of a multispecific seagrass meadow by green turtles Chelonia mydas at Mayotte Island. Marine Biology, 157, 2581-2590.

BJORNDAL, K.A. (2017) Foraging ecology and nutrition of sea turtles. In The Biology of Sea Turtles, Vol. I. (eds P.L. Lutz \& J.A. Musick), pp. 213-246. CRC Press, Boca Raton, USA.

Bolten, A.B. (2003) Variation in sea turtle life history patterns: neritic vs. oceanic developmental stages. The Biology of Sea Turtles, 2, 243-257.

Bowen, B.W. \& KarL, S. (2007) Population genetics and phylogeography of sea turtles. Molecular Ecology, 16, 4886-4907.

Broderick, A.C., Coyne, M.S., Fuller, W.J., Glen, F. \& Godley, B.J. (2007) Fidelity and over-wintering of sea turtles. Proceedings of the Royal Society of London B: Biological Sciences, 274, 1533-1539.

Cardona, L., Aguilar, A. \& Pazos, L. (2009) Delayed ontogenic dietary shift and high levels of omnivory in green turtles (Chelonia mydas) from the NW coast of Africa. Marine Biology, 156, 1487-1495.

CARr, T. \& CARr, N. (1991) Surveys of the sea turtles of Angola. Biological Conservation, 58, 19-29.

Casale, P., Broderick, A.C., Freggi, D., Mencacci, R., Fuller, W.J., Godley, B.J. \& Luschi, P. (2012) Long-term residence of juvenile loggerhead turtles to foraging grounds: a potential conservation hotspot in the Mediterranean. Aquatic Conservation: Marine and Freshwater Ecosystems, 22, 144-154.

Casale, P. \& Heppell, S.S. (2016) How much sea turtle bycatch is too much? A stationary age distribution model for simulating population abundance and potential biological removal in the Mediterranean. Endangered Species Research, 29, 239-254.

Chevis, M.G., Godley, B.J., Lewis, J.P., Lewis, J.J., Scales, K.L. \& Graham, R.T. (2017) Movement patterns of juvenile hawksbill turtles Eretmochelys imbricata at a Caribbean coral atoll: long-term tracking using passive acoustic telemetry. Endangered Species Research, 32, 309-319.

Congo Marine (2018) Strategic Information to Support Marine Spatial Planning. Republic of the Congo Version I May 2018. Unpublished report. Centre for Ecology and Conservation, University of Exeter, Cornwall, UK.

Coyne, M.S. \& Godley, B.J. (2005) Satellite Tracking and Analysis Tool (STAT): an integrated system for archiving, analyzing and mapping animal tracking data. Marine Ecology Progress Series, $301,1-7$.

Dawson, T.M., Formia, A., Agamboué, P.D., Asseko, G.M., Boussamba, F., Cardiec, F. et al. (2017) Informing marine protected area designation and management for nesting olive ridley sea turtles using satellite tracking. Frontiers in Marine Science, 4, 312.

De Solla, S.R., Bonduriansky, R. \& Brooks, R.J. (1999) Eliminating autocorrelation reduces biological relevance of home range estimates. Journal of Animal Ecology, 68, 221-234.

Doherty, P., Baxter, J., Godley, B., Graham, R., Hall, G., Hall, J. et al. (2017) Testing the boundaries: seasonal residency and inter-annual site fidelity of basking sharks in a proposed Marine Protected Area. Biological Conservation, 209, 68-75.

Duncan, E.M., Botterell, Z.L., Broderick, A.C., Galloway, T.S., Lindeque, P.K., Nuno, A. \& Godley, B.J. (2017) A global review of marine turtle entanglement in anthropogenic debris: a baseline for further action. Endangered Species Research, 34, 431-448.

Formia, A., Tiwari, M., Fretey, J. \& Billes, A. (2003) Sea turtle conservation along the Atlantic coast of Africa. Marine Turtle Newsletter, 100, 33-37.

Freitas, C., Lydersen, C., Fedak, M.A. \& Kovacs, K.M. (2008) A simple new algorithm to filter marine mammal Argos locations. Marine Mammal Science, 24, 315-325.
Fretey, J. (2001) Biogeography and Conservation of Marine Turtles of the Atlantic Coast of Africa. Biogéographie et Conservation des Tortues Marines de la Côte Atlantique de l'Afrique. Convention on the Conservation of Migratory Species of Wild Animals (CMS). CMS Technical Series Publication No. 6. United Nations Environment Programme/Convention on Migratory Species Secretariat, Bonn, Germany.

Garnier, J., Hill, N., Guissamulo, A., Silva, I., Witt, M. \& Godley, B. (2012) Status and community-based conservation of marine turtles in the northern Querimbas Islands (Mozambique). Oryx, 46, 359-367.

Girard, A., LouvinGuila, H.D., Breheret, N., Monisinjon, J., Charra, M., Protat, E. et al. (2014) Les engins et techniques de pêche utilisés dans la baie de Loango, République du Congo, et leurs incidences sur les prises accessoires. Cybium, 38, 117-131.

Giresse, P., Kouyoumontzakis, G. \& Moguedet, G. (1980) Carte sédimentologique du plateau continental du Congo à l'échelle de 1:200 ooo, Mayumba. Notice explicative no. 85. ORSTOM. Université Marien N'Gouabi, Brazzaville, Republic of the Congo.

Gitzen, R.A., Millspaugh, J.J. \& Kernohan, B.J. (2006) Bandwidth selection for fixed-kernel analysis of animal utilization distributions. Journal of Wildlife Management, 70, 1334-1344.

Godgenger, M.-C., Breheret, N., Bal, G., N’Damité, K., Girard, A. \& Girondot, M. (2009) Nesting estimation and analysis of threats for Critically Endangered leatherback Dermochelys coriacea and Endangered olive ridley Lepidochelys olivacea marine turtles nesting in Congo. Oryx, 43, 556-563.

Godley, B.J, Blumenthal, J., Broderick, A., Coyne, M., Godfrey, M., HAW KES, L. \& WitT, M. (2008) Satellite tracking of sea turtles: where have we been and where do we go next. Endangered Species Research, 4, 3-22.

Godley, B.J., Richardson, S., Broderick, A.C., Coyne, M.S., GLEN, F. \& HAYs, G.C. (2002) Long-term satellite telemetry of the movements and habitat utilisation by green turtles in the Mediterranean. Ecography, 25, 352-362.

Graham, R.T., Witt, M.J., Castellanos, D.W., Remolina, F., Maxwell, S., Godley, B.J. \& Hawkes, L.A. (2012) Satellite tracking of Manta rays highlights challenges to their conservation. PLOS ONE, 7, e36834.

Hamann, M., Godfrey, M.H., Seminoff, J.A., Arthur, K., Barata, P.C.R., BJORNDAL, K.A. et al. (2010) Global research priorities for sea turtles: informing management and conservation in the 21st century. Endangered Species Research, 11, 245-269.

Hays, G.C., Alcoverro, T., Christianen, M.J.A., Duarte, C.M., Hamann, M., Macreadie, P.I. et al. (2018) New tools to identify the location of seagrass meadows: marine grazers as habitat indicators. Frontiers in Marine Science, 5, 9.

Hays, G.C., Ferreira, L.C., Sequeira, A.M., Meekan, M.G., Duarte, C.M., Bailey, H. et al. (2016) Key questions in marine megafauna movement ecology. Trends in Ecology \& Evolution, $31,463-475$.

Hazen, E.L., Maxwell, S.M., Bailey, H., Bograd, S.J., Hamann, M., Gaspar, P. et al. (2012) Ontogeny in marine tagging and tracking science: technologies and data gaps. Marine Ecology Progress Series, 457, 221-240.

Hirth, H.F. (1997) Synopsis of the biological data on the green turtle Chelonia mydas (Linnaeus 1758).

Hoffmann, M., Hilton-Taylor, C., Angulo, A., Böhm, M., Brooks, T.M., Butchart, S.H. et al. (2010) The impact of conservation on the status of the world's vertebrates. Science, 330, 1503-1509.

IUCN (2017) The IUCN Red List of Threatened Species. Version 2017-3. iucnredlist.org [accessed 4 June 2018]. 
Jeffers, V.F. \& Godley, B.J. (2016) Satellite tracking in sea turtles: how do we find our way to the conservation dividends? Biological Conservation, 199, 172-184.

Lewison, R.L., Crowder, L.B., Read, A.J. \& Freeman, S.A. (2004) Understanding impacts of fisheries bycatch on marine megafauna. Trends in Ecology \& Evolution, 19, 598-604.

Luschi, P., Hays, G.C. \& PAPI, F. (2003) A review of long-distance movements by marine turtles, and the possible role of ocean currents. Oikos, 103, 293-302.

Malounguila-Nganga, D., Giresse, P., Boussafir, M. \& Miyouna, T. (2017) Late Holocene swampy forest of Loango Bay (Congo). Sedimentary environments and organic matter deposition. Journal of African Earth Sciences, 134, 419-434.

Mansfield, K.L., Wyneken, J., Porter, W.P. \& Luo, J. (2014) First satellite tracks of neonate sea turtles redefine the 'lost years' oceanic niche. Proceedings of the Royal Society B: Biological Sciences, 281, 20133039.

Maxwell, S.M., Breed, G., Nickel, B., Makanga-Bahouna, J., Pemo-Makay a, E., PARnell, R. et al. (2011) Using satellite tracking to optimize protection of long-lived marine species: olive ridley Sea turtle conservation in Central Africa. PLOS ONE, 6, e19905.

Mazaris, A.D., Almpanidou, V., Wallace, B.P., Pantis, J.D. \& Schofield, G. (2014) A global gap analysis of sea turtle protection coverage. Biological Conservation, 173, 17-23.

Metcalfe, K., Agamboué, P.D., Augowet, E., Boussamba, F., CArdiec, F., Fay, J.M. et al. (2015) Going the extra mile: ground-based monitoring of olive ridley turtles reveals Gabon hosts the largest rookery in the Atlantic. Biological Conservation, 190, 14-22.

Metcalfe, K., Bréheret, N., Chauvet, E., Collins, T., Curran, B.K., PARnelL, R.J. et al. (2018) Using satellite AIS to improve our understanding of shipping and fill gaps in ocean observation data to support marine spatial planning. Journal of Applied Ecology, $55,1834-1845$.

Metcalfe, K., Collins, T., Abernethy, K.E., Boumba, R., Dengui, J.C., Miyalou, R. et al. (2017) Addressing uncertainty in marine resource management; combining community engagement and tracking technology to characterise human behavior. Conservation Letters, 10, 460-469.

Nelms, S.E., Piniak, W.E.D., Weir, C.R. \& Godley, B.J. (2016) Seismic surveys and marine turtles: an underestimated global threat? Biological Conservation, 193, 49-65.

Our Ocean (2016) Our Ocean Conference Commitments. ourocean2016.org/commitments [accessed 4 June 2018].

Patrício, A.R., Formia, A., Barbosa, C., Broderick, A.C., Bruford, M., Carreras, C. et al. (2017) Dispersal of green turtles from Africa's largest rookery assessed through genetic markers. Marine Ecology Progress Series, 569, 215-225.

Pikesley, S.K., Agamboue, P.D., Bayet, J.P., Bibang, J.N., Bonguno, E.A., Boussamba, F. et al. (2018) A novel approach to estimate the distribution, density and at-sea risks of a centrally placed mobile marine vertebrate. Biological Conservation, 221, 246-256.

R Core TеAм (2018) R: a Language and Environment for Statistical Computing. R Foundation for Statistical Computing, Vienna, Austria. R-project.org [accessed 23 July 2019].

Rees, A., Alfaro-Shigueto, J., Barata, P., Bjorndal, K., Bolten, A., BOURJEA, J. et al. (2016) Are we working towards global research priorities for management and conservation of sea turtles? Endangered Species Research, 31, 337-382.
Scott, R., Hodgson, D.J., Witt, M.J., Coyne, M.S., Adnyana, W., Blumenthal, J.M. et al. (2012) Global analysis of satellite tracking data shows that adult green turtles are significantly aggregated in Marine Protected Areas. Global Ecology and Biogeography, 21, 1053-1061.

Sprogis, K.R., Raudino, H.C., Rankin, R., MacLeod, C.D. \& BEJDER, L. (2016) Home range size of adult Indo-Pacific bottlenose dolphins (Tursiops aduncus) in a coastal and estuarine system is habitat and sex-specific. Marine Mammal Science, 32, 287-308.

Stokes, K., Broderick, A., Canbolat, A., Candan, O., Fuller, W., GLEN, F. et al. (2015) Migratory corridors and foraging hotspots: critical habitats identified for Mediterranean green turtles. Diversity and Distributions, 21, 665-674.

Tomás, J., Godley, B.J., Castroviejo, J. \& Raga, J.A. (2010) Bioko: critically important nesting habitat for sea turtles of West Africa. Biodiversity and Conservation, 19, 2699-2714.

Varo-Cruz, N., Bermejo, J.A., Calabuig, P., Cejudo, D., Godley, B.J., LOPEZ-JURADO, L.F. et al. (2016) New findings about the spatial and temporal use of the Eastern Atlantic Ocean by large juvenile loggerhead turtles. Diversity and Distributions, 22, 481-492.

Wallace, B.P., Brosnan, T., McLamb, D., Rowles, T., Ruder, E., Schroeder, B. et al. (2017) Effects of the Deepwater Horizon oil spill on protected marine species. Endangered Species Research, $33,1-7$.

Weatherall, P., Marks, K.M., Jakobsson, M., Schmitt, T., Tani, S., Arndt, J.E. et al. (2015) A new digital bathymetric model of the world's oceans. Earth and Space Science, 2, 331-345.

Wildermann, N.E., Gredzens, C., Avens, L., Barrios-Garrido, H.A., Bell, I., Blumenthal, J. et al. (2018) Informing research priorities for immature sea turtles through expert elicitation. Endangered Species Research, 37, 55-76.

Williams, J.L., Pierce, S.J., Rohner, C.A., Fuentes, M.M. \& Hamann, M. (2017) Spatial distribution and residency of green and loggerhead sea turtles using coastal reef habitats in Southern Mozambique. Frontiers in Marine Science, 3, 288.

Winton, M.V., Fay, G., Haas, H.L., Arendt, M., Barco, S., James, M.C. et al. (2018) Estimating the distribution and relative density of satellite-tagged loggerhead sea turtles using geostatistical mixed effects models. Marine Ecology Progress Series, 586, 217-232.

Witt, M., Akesson, S., Broderick, A.C., Coyne, M., Ellick, J., Formia, A. et al. (2010) Assessing accuracy and utility of satellite-tracking data using Argos-linked Fastloc-GPS. Animal Behaviour, 80, 571-581.

Witt, M.J., Baert, B., Broderick, A.C., Formia, A., Fretey, J. Gibudi, A. et al. (2009) Aerial surveying of the world's largest leatherback turtle rookery: a more effective methodology for large-scale monitoring. Biological Conservation, 142, 1719-1727.

Witt, M.J., Broderick, A.C., Coyne, M., Formia, A., Ngouessono, S., Parnell, R.J. et al. (2008) Satellite tracking highlights difficulties in the design of effective protected areas for leatherback turtles during the internesting period. Oryx, 42, 296-300.

$\mathrm{XU}, \mathrm{H}$. (2006) Modification of normalised difference water index (NDWI) to enhance open water features in remotely sensed imagery. International Journal of Remote Sensing, 27, 3025-3033.

Ylitalo, G.M., Collier, T.K., Anulacion, B.F., Juaire, K., Boyer, R.H., DA SiLva, D.A. et al. (2017) Determining oil and dispersant exposure in sea turtles from the northern Gulf of Mexico resulting from the Deepwater Horizon oil spill. Endangered Species Research, $33,9-24$. 